Saudi Journal of Business and Management Studies Abbreviated Key Title: Saudi J Bus Manag Stud ISSN 2415-6663 (Print) |ISSN 2415-6671 (Online) Scholars Middle East Publishers, Dubai, United Arab Emirates Journal homepage: http://scholarsmepub.com/sjbms/

Original Research Article

\title{
Fiscal Policy and Economic Growth in Nigeria: An ARDL, Bound Test and ECM Approach
}

\author{
Amusa Bolanle Olubunmi ${ }^{1 *}$, Nwagwu Chinedu John ${ }^{2}$, Yusuf Modupe Ololade ${ }^{3}$, Sokunbi Gbenro Matthew ${ }^{4}$ \\ ${ }^{1}$ Department of Business Administration and Management, Gateway (ICT) Polytechnic, Saapade, Ogun State, Nigeria \\ ${ }^{2}$ Department of Business Administration, Lagos State University, Lagos, Nigeria \\ ${ }^{3}$ Department of Economics, Michael Otedaola College of Primary Education, Lagos, Nigeria \\ ${ }^{4}$ Department of Economics, Michael Otedaola College of Primary Education, Lagos, Nigeria
}

DOI: $10.36348 /$ SJBMS.2019.v04i10.002 $\quad$ | Received: 18.09.2019| Accepted: 07.10.2019 | Published: 30.10 .2019

*Corresponding author: Amusa Bolanle Olubunmi

\section{Abstract}

The aim of this study is to examine the relationship between fiscal policy and economic growth in which past studies have not fully explored in Nigeria. Data was collected from the Central Bank of Nigeria Statistical Bulletin from 1990 to 2017 and the study employed the Autoregressive Distributed Lag (ARDL) model and Error Correction Model (ECM) to address its objective. Consequently, the major findings that originated from the work could be submitted as follows. The result of ECM term confirmed that about $39 \%$ of the total disequilibrium in the previous year would be corrected in the current year. Therefore, it will take about two (2) years for the system to adjust back to its long run equilibrium path. Meanwhile, the estimated result shows that economic growth and government revenue have a significant positive relationship in Nigeria in the short run but the relationship becomes negative in the long run. However, recurrent expenditure has a significant negative relationship with economic growth in the short run but the relationship becomes insignificant in the long run. However, inflation rate has a significant positive relationship with economic growth in both short run and long run. Due to the findings that originated in this study, this paper makes the following recommendations for the policy makers in Nigeria that if the economic growth is the target of the policy makers, manipulating fiscal policy variables such as government revenue, capital expenditure and inflation rate appropriately will increase economic growth in the short run and the long run.

Keywords: Fiscal Policy; Economic Growth: ARDL.

Copyright @ 2019: This is an open-access article distributed under the terms of the Creative Commons Attribution license which permits unrestricted use, distribution, and reproduction in any medium for non-commercial use (NonCommercial, or CC-BY-NC) provided the original author and source are credited.

\section{INTRODUCTION}

Most of the African countries, including Nigeria are confronted with various developmental issues like perpetual price-instability, high level of unemployment rate, persistent exchange rates volatility, inequitable distribution of income, unfavourable balance of payments, low growth rate and high level of abject poverty $[1,2]$.

In Nigeria, few of the most paramount macroeconomic policies that cannot be undermined are monetary policy and fiscal policy. For instance, the monetary policy is primarily formulated in Nigeria to maintain price and exchange rate stability in order to achieve a sustainable economic growth and competitive external sector [3]. It instructive to state that the effectiveness or otherwise of monetary policy in achieving its target objectives is a function of operating economic environment, the institutional framework adopted, and the choice and mix of the instruments used.

Similarly, fiscal policy uses important parameters which span from taxation, budget and quotas. These parameters induce government revenue and expenditure with a view to achieving a sustainable economic growth which monetary policy also intends to achieve. It is expected that tax revenue will rise due to 
the expansion of the economy all things being equal, even when the fiscal policy remains constant. Meanwhile, government expenditure could further increase as a result of an increase in revenue from taxes. This leads to more expansion of the economy given the fact that such spending is channeled into productivity activities that complement private investment. Therefore, fiscal policy could be used to stimulate the economy via manipulation of taxes and expenditure.

In Nigeria, despite the fact that there have been an increase in expenditure by different successive government in the last few decades, yet in 2013 the country registered an average per capita income which is lower than what was attainable at the end of the 1970s. In the same vein, GDP growth rate declined from $7.8 \%$ in 2010 to $0.8 \%$ in 2017 [4]. Nigeria is also among the countries experiencing lowest investment rate in the globe. Meanwhile, it has been argued that the pursuit of sound monetary and fiscal policies in conjunction with good governance has the capacity to propel a strong moderating inducement on the exogenous factors that have constituted an impediment to double digit growth rate in the Nigerian economy [5]. Moreover, increase in expenditure should address economic growth challenges and the worrisome level of unemployment rate in Nigeria, the reverse is the case. Total expenditure and rate of unemployment have a direct relationship over time in Nigeria. This is because recurrent expenditure consumes a greater percentage of the total expenditure in Nigeria. For instance, in 2000, $66 \%$ of the total expenditure went on recurrent which rose to $79 \%$ in 2010 [6]. This implies that less percentage of the total expenditure has been spent on capital projects that could address infrastructural deficit and consequently derive economic growth in the country. In view of the above it is pertinent for this study to critically examine the nexus between fiscal policy variables and economic growth in which past empirical studies have not fully explored in the recent time.

\section{LITERATURE REVIEW}

Agu et al. [7] employed ordinary least square (OLS) to determine the impact of various components of fiscal policy on economic growth in Nigeria between 1961 and 2010. The findings that came up in the study show that total government expenditures have tendency to rise with government revenue, but expenditures increase faster than revenue. Therefore, in public spending, it is important to note that the effectiveness of the private sector depends on the stability and predictability of the public incentive framework, which promotes or crowds out private investment Falade and Folorunsho [8] examined the relative effectiveness of fiscal and monetary policy instruments on economic growth sustainability in Nigeria with the application of error correction mechanism between 1970 and 2013 . Data were sourced mainly from Statistical Bulletin published by the Central Bank Nigeria. The authors discovered that the current level of exchange rate and its immediate past level, domestic interest rate, current level of government revenue and current level of money supply are the appropriate policy instrument mix in propelling growth of the Nigerian economy in the short and long run. Similarly, Ogege and Shiro [9] analyzed the dynamics of monetary and fiscal policies on economic growth in Nigeria. The study concluded that both monetary and fiscal policy brought about economic growth in the country. Ogbole, Amadi, and Essi [10] assessed a comparative impact of fiscal policy on economic growth in Nigeria during regulation and deregulation periods with the application of econometric technique. It was discovered from the paper that the effectiveness of fiscal policy in stimulating economic growth during and after regulation period was not the same. Consequently, Effiong [11] analyzed the link between fiscal, monetary policies and the development of the Nigerian stock market. The author argued that monetary and fiscal policy mix brought about a significant role on the development of stock market in Nigeria. Omitogun and Ayinla [12] critically verified the linkage between fiscal policy and the achievement of sustainable economic growth in Nigeria with the aid of Solow growth model and OLS technique. The authors opined that fiscal policy has not been effective in promoting sustainable economic growth in Nigeria. Enahoro [13] argued that fiscal and monetary policies facilitated operational efficiency financial institutions in Nigeria by causing a decline in financial indiscipline in both financial and fiscal systems. It was concluded from the study that fiscal and monetary policies orchestrated government to commit budgetary management that addresses anomalies in the financial system. Sanni et al. [14] submitted that none of the monetary and fiscal policies could be said to be superior to another. However, a proper mix of the policies could bring a better economic growth.

In the same vein, Chuku [15] adopted a vector auto-regression (VAR) model to investigate the monetary and fiscal policy interactions in Nigeria from 1970 to 2008 . It was posited that monetary and fiscal policies have a counteractive interaction from 1980 to 1994, whereas no symmetric pattern of interaction was noticed between the two policies at other periods. Victor and Marcos [11] assessed how economic, political, and institutional factors constituted constraints to the implementation of fiscal policy in sub-Saharan Africa. The authors reported that there was a high tendency that planned fiscal adjustments or expansions are less likely to be implemented. Hilderbrand [16] analyzed the nexus between the value, interaction of both fiscal austerity and structural reforms. The author argued that structural reform process did not produce immediate results but reverse was the case of fiscal austerity. In another perspective, Adeoye [17] investigated aftermath effect of fiscal policy on economic growth in Nigeria from 1970 to 2002. It was 
discovered from the paper that public investment had a negative effects on output growth in the country. This showed that public expenditure caused a crowding out effect on private investment in Nigeria.

In conclusion, literature on macroeconomic policy and economic growth is ongoing in Nigeria, and empirical studies about policy mix are inconclusive in the country. Hence, the relevance of this study

\section{METHODOLOGY}

The data for the empirical analysis in this paper are extracted from secondary sources. To be explicit, data for real GDP, inflation rate, government expenditure and revenue were sourced from CBN statistical Bulletin. E-Views software was employed for the running of the data.

\section{Model Specification}

RGDP = F (Infl, CE, RE, GR)

If model 1 is linearized to form model 2



\section{ARDL and ECM Model Specification}

Various diagnostic tests such as unit root test and Bound Test performed on data used to capture the variables of interest necessitated the choice of ARDL and ECM in this study. Due to different orders of integration of the variables i.e. $\mathrm{I}(1)$ and $\mathrm{I}(0)$, the paper utilizes autoregressive lag model to address its objective $[18,19]$. In a general form, ARDL and ECM models could be specified as follows

$$
\begin{aligned}
& \Delta \operatorname{LnRGDP}_{t}=\beta_{0}+\sum_{i=1}^{p} \beta_{1} \Delta \operatorname{Ln} R G D P_{t-1}+\sum_{i=0}^{p} \beta_{2} \Delta \operatorname{Infl}_{t-1}+\sum_{i=0}^{p} \beta_{3} \Delta \operatorname{LnCE}_{t-1}+\sum_{i=0}^{p} \beta_{4} \Delta \operatorname{LnRE}_{t-1}+ \\
& \sum_{i=0}^{p} \beta_{5} \Delta \operatorname{LnGR}_{t-1}+E C M_{t-1}+\sum_{i=1}^{p} \beta_{6} \operatorname{Ln} R G D P_{t-1}+\sum_{i=0}^{p} \beta_{7} \operatorname{Infl}_{t-1}+\sum_{i=0}^{p} \beta_{8} \operatorname{LnCE}_{t-1}+ \\
& \sum_{i=0}^{p} \beta_{9} L n R E_{t-1}+\sum_{i=0}^{p} \beta_{10} \operatorname{LnGR}_{t-1}+\mu \mathrm{i}-\cdot-----(3)
\end{aligned}
$$

Where RGDP proxy's economic growth, Infl denotes inflation rate, $\mathrm{CE}$ is used to represent government capital expenditure, RE means government recurrent expenditure, GR connotes total government revenue, ECM measures the speed of adjustment between short run and long run relationship and $\mu_{\mathrm{i}}$ is error term. $\mathrm{t}=1990-2017$.
Meanwhile, term $\beta_{1}-\beta_{5}$ is measures short run parameters/ coefficients meanwhile $\beta_{6}$ $\beta_{10}$ measures long run parameters. It is expected that $\beta_{1}-$ $\beta_{10}>0$.

\section{RESULTS AND DISCUSSION}

Table-2: Descriptive Statistics of Annual Data Series (1990-2017)

\begin{tabular}{|l|l|l|l|l|l|l|}
\hline Descriptive Statistics & LNExch & LnRGDP & Infl, & LnCE & LnGR & LnRE \\
\hline Mean & 4.300743 & 42.44046 & 18.71679 & 26.43649 & 28.23554 & 27.22300 \\
\hline Median & 4.815250 & 31.28159 & 12.55000 & 26.69591 & 28.61158 & 27.67558 \\
\hline Maximum & 5.857933 & 346.1660 & 72.84000 & 27.81334 & 30.03949 & 29.06108 \\
\hline Minimum & 2.084156 & 30.60445 & 5.380000 & 23.90340 & 25.30925 & 24.31288 \\
\hline Std. Deviation & 1.061811 & 59.52657 & 17.42350 & 1.174559 & 1.540107 & 1.565270 \\
\hline Skewness & -0.709526 & 5.003169 & 1.958346 & -0.788727 & -0.573464 & -0.481538 \\
\hline Kurtosis & 2.095351 & 26.03362 & 5.646040 & 2.485971 & 1.957561 & 1.860208 \\
\hline Jargue-Bera & 3.304115 & 735.7866 & 26.06566 & 3.211354 & 2.802474 & 2.597748 \\
\hline Probability & 0.191655 & 0.000000 & 0.000002 & 0.200754 & 0.246292 & 0.272839 \\
\hline Sum & 120.4208 & 1188.333 & 524.0700 & 740.2217 & 790.5951 & 762.2440 \\
\hline Sum. Sq. Deviation & 30.44095 & 95672.15 & 8196.619 & 37.24887 & 64.04208 & 66.15188 \\
\hline Observation & 28 & 28 & 28 & 28 \\
\hline
\end{tabular}

Data series is near symmetry the above table presents descriptive statistics of the data employed for empirical analysis in this paper. This provides a crucial information about the distribution of the sample series. The estimated results in the table shows that the values of mean and median of the variables exchange rate, capital expenditure, recurrent expenditure and government revenue are almost identical apart from real
GDP and inflation which show a slight difference. This proves that the distribution of the. Because distribution of data series is said to be perfectly symmetrical if the values of mean, mode and median of such data series are the same [20]. The value of Kurtosis of the variables are not far from 3 except that of real GDP. This is also attests to the symmetrical nature of the data series employed for the analysis. 
Table-2: Unit Root Test

\begin{tabular}{|l|l|l|l|l|l|l|}
\hline \multirow{2}{*}{ Variables } & \multicolumn{2}{|l|}{ ADF Test } & \multicolumn{2}{l|}{ PP Test } \\
\cline { 2 - 7 } & Level & $\mathbf{1}^{\text {st }}$ Difference & $\begin{array}{l}\text { Remar } \\
\text { ks }\end{array}$ & Level & $\mathbf{1}^{\text {st }}$ Difference & $\begin{array}{l}\text { Remar } \\
\text { ks }\end{array}$ \\
\hline LnRGDP & $-2.976263 * * *$ & & $\mathrm{I}(0)$ & $-2.976263 * * *$ & & $\mathrm{I}(0)$ \\
\hline LnExch & $-2.976263 * * *$ & $-2.981038^{* * *}$ & & $-2.976263 * * *$ & $-2.981038^{* * *}$ & \\
\hline LnRE & $-2.976263 * * *$ & $-2.981038^{* * *}$ & $\mathrm{I}(1)$ & $-2.976263 * * *$ & $-2.981038^{* * *}$ & $\mathrm{I}(1)$ \\
\hline LGR & $-2.976263 * * *$ & $-2.981038^{* * *}$ & $\mathrm{I}(1)$ & $-2.976263 * * *$ & $-2.981038^{* * *}$ & $\mathrm{I}(1)$ \\
\hline LCE & $-2.976263 * * *$ & $-2.981038^{* * *}$ & $\mathrm{I}(1)$ & $-2.976263 * * *$ & $-2.981038^{* * *}$ & $\mathrm{I}(1)$ \\
\hline Infl & $-2.976263 * * *$ & $-2.981038^{* * *}$ & $\mathrm{I}(1)$ & $-2.976263 * * *$ & $-2.981038^{* * *}$ & $\mathrm{I}(1)$ \\
\hline
\end{tabular}

Source: Authors` Computation (2019) ***\%5 level

This study employs a time series data for its analysis. However, non-stationarity of data constitutes a problem in time series data analysis because it could reduce the validity of economic forecast based on such data. In order to overcome the above problem in this study an attempt has been made to utilize the standard Augmented Dickey-Fuller (ADF) and Phillips-Perron
(PP) tests to examine the stationarity or otherwise of the data. Consequently, the results of the estimated Augmented Dickey-Fuller (ADF) and Philip Perron tests in the above table indicate that all the macroeconomic data in this work were not stationary in their level form, except real GDP which was stationary in its native form.

Table-3: ARDL Bounds Test

\begin{tabular}{|l|c|c|}
\hline \multicolumn{3}{|c|}{ Sample: 1992 2017 } \\
\hline \multicolumn{3}{|c|}{ Included observations: 26 } \\
\hline Null Hypothesis: No long-run relationships exist \\
\hline Test Statistic & Value & $\mathrm{k}$ \\
\hline F-statistic & 5.712113 & 4 \\
\hline \multicolumn{3}{|c|}{ Critical Value Bounds } \\
\hline Significance & I0 Bound & I1 Bound \\
\hline $10 \%$ & 2.45 & 3.52 \\
\hline $5 \%$ & 2.86 & 4.01 \\
\hline $2.5 \%$ & 3.25 & 4.49 \\
\hline $1 \%$ & 3.74 & 5.06 \\
\hline
\end{tabular}

Source: Authors`Computation (2019)

Having established that the pre-estimation test of data employed for this work shows that the dataset is a combination of $\mathrm{I}(0)$ and $\mathrm{I}(1)$. Meaning that the dataset is a combination of stationarity and non-stationarity data. It is instructive to determine the existence or otherwise of the long run equilibrium relationship among these set of variables with the application of Bound Test [19, 18]. Consequently, table 3 confirms a presence of cointegrating relationship among the variables in the model since the Null hypothesis of no long run relationship could not be accepted because the upper and lower Critical Value Bounds at all level of significance is less than the value of F-Statistic. Hence, it could be submitted that real GDP and other macroeconomic variables in the model have a long rub relationship. This justifies the need to estimate both short run and long run relationship among these variables in this paper.

Table-4: Parsimonious Short Run and Long Run Regression Estimates

Dependent Variable: LnRGDP

\begin{tabular}{|l|l|l|l|l|l|}
\hline Short Run & coefficient & T-statistics & Long Run & coefficient & T-statistics \\
\hline DLnRGDP(-1) & -0.520527 & -4.915069 & LnRGDP(-1) & 0.157342 & 0.354443 \\
\hline DLnGR & 64.16151 & 2.068742 & LnGR & 66.53996 & 1.405613 \\
\hline DLnRE & -51.34061 & 1.857096 & LnRE & -37.97695 & -0.299985 \\
\hline DLnCA & 1.222305 & 0.121464 & LnCA & 10.43340 & 0.6237 \\
\hline DInfl & 5.188582 & 7.307590 & Infl & 5.045912 & 5.428183 \\
\hline ECM & -0.397019 & 2.227675 & R-squared & 0.658845 & \\
\hline R-Squared & 0.900568 & & A.R-squared & 0.454152 & \\
\hline Adj.R-Squared & 0.822442 & & DWstat & 1.797389 & \\
\hline DWstat & 2.031963 & & & & \\
\hline
\end{tabular}

Source: Authors`Computation (2019) 
The table above presents the result of both the short and long run relationship between economic growth and other macroeconomic variables. All explanatory variables have the expected sign both in the short and the long run except recurrent expenditure. Also, the error correction model (ECM) which shows the speed of adjustments back to equilibrium in the estimated model is negative and significant. The speed of adjustment for correcting disequilibrium from the previous year to equilibrium in current year is $39 \%$ as shown by the coefficient of ECM. In another words, this implies that an approximately 39\% of disequilibrium from the previous year's shock converge to the long-run equilibrium in the current year.

Similarly, the estimated result shows that government revenue and economic growth have a significant positive relationship in Nigeria in the short run but the relationship becomes negative in the long run, though not significant. This finding is in line with the submission of Falade and Folorunsho [8], Ogege and Shiro [9] in related studies but different methodologies in Nigeria. However, recurrent expenditure has a significant negative relationship with economic growth in the short run but the result becomes insignificant in the long run. The negative impact of recurrent expenditure on economic growth in Nigeria could be as a result of huge part of this fund that goes on debt servicing on annual basis. Meanwhile, capital expenditure has an insignificant positive impact on economic growth both in the short run and long run. The reason for an insignificant result might be as a result of investment on white elephant projects by the Nigerian government or embezzlement of funds benchmarked for capital projects by the public office holders in the country. In addition, inflation rate has a significant positive relationship with economic growth in both short run and long run. This implies that inflation rate contributes to economic growth in Nigeria over time.

Therefore, government revenue and capital expenditure have a positive impact on economic growth in Nigeria; this study submits that fiscal policy has the tendency to stimulate economic growth in the country. This conclusion is supported by the propositions of Nworji, Okwu, Obiwuru, and Nworji [21] Medee and Nenbee [23], Wu, Tang, and Lin [23] and Philip [24]. But contradicts the submission of Omitogun and Ayinla [9]

\section{CONCLUSION AND RECOMMENDATIONS}

This paper has examined the relationship between fiscal policy and economic growth in Nigeria between 1990 and 2017 using Bound Test, ARDL and ECM model. The findings of this study could be summarized below; the error correction term showed that about $39 \%$ of the total disequilibrium in the previous year due to shock was corrected in the current year. Government revenue and economic growth have a significant positive relationship in Nigeria in the short run but negative in the long run, though not significant. However, recurrent expenditure has a significant negative relationship with economic growth in the short run but the result becomes insignificant in the long run. Capital expenditure has an insignificant positive impact on economic growth both in the short run and long run. Furthermore, inflation rate has a significant positive relationship with economic growth in both short run and long run. It could be concluded that government revenue and capital expenditure have a positive impact on economic growth in Nigeria, Therefore, this study submits that fiscal policy has the tendency to stimulate economic growth in the country. As a result of the findings that emerged in this study, it is imperative that the following recommendations are made for the makers in Nigeria that if the economic growth is the target of the policy makers, manipulating fiscal policy variables such as government revenue, capital expenditure and inflation rate will increase economic growth in the short run and the long run. Also, capital expenditure should be chandelled towards more productive sectors of the economy to ensure a sustainable economic growth in the country.

\section{REFERENCE}

1. Adigwe, P. K., Echekoba F.N., \& Justus Onyeagba, B.C. (2015). Monetary Policy and Economic Growth in Nigeria: A Critical Evaluation. IOSR Journal of Business and Management (IOSR-JBM), 17(2):110-119.

2. Enoma, A., \& Mustafa, I. (2011). The Impact of Financial Sector Reforms on Non-Oil Export in Nigeria, Journal of Economics, 2(2):115-120

3. Sanusi, L.S. 2012. Banking reforms and its Implications on the Nigeria Economy

4. World Bank. (2018). World Development Indicators. Washington D.C.

5. Soludo, C, (2001). 'Debt, Poverty and Inequality: Towards an Exit Strategy for Nigeria and Africa.' in Proceedings of International Conference on Sustainable Debt Strategy. Abuja. Nigeria

6. CBN (2018). Statistical Bulletin. Central Bank of Nigeria.

7. Agu1, S. U., Okwo, I. M., Ugwunta, O. D., \& Idike, A. (2015). Fiscal Policy and Economic Growth in Nigeria: Emphasis on Various Components of Public Expenditure. SAGE Open: 1-12.

8. Falade, O. E. and Folorunso, B. A. (2015). Fiscal and Monetary Policy Instruments and Economic Growth Sustainability in Nigeria American Journal of Economics, 5(6): 587-594

9. Ogege, S. and Shiro, A. A. (2012). 'The Dynamics of Monetary and Fiscal Policy as a Tool for Economic Growth: Evidence from Nigeria.' Journal of Management and Sustainability, 2(2): 247-258.

10. Ogbole, F. O., Amadi, S. N., \& Essi, I. D. (2011). Fiscal policy: Its impact on economic growth in 
Nigeria (1970-2006). Journal of Economics and International Finance, 3, 407-417.

11. Effiong, C., Igbeng, E., \& Tapang, T. (2012). 'The Accounting Implications of Fiscal and Monetary Policies on the Development of the Nigerian Stock Market: 1992-2011.Journal of Economics and Sustainable Development, 3(11): 83-98.

12. Omitogun, O., \& Ayinla, T. A. (2007). Fiscal policy and Nigeria economic retirement. Available from www.termpaperwarehouse.com

13. Enahoro, J., Jayeola, O. Onou, P. (2013). 'Operational Performance of Fiscal and Monetary Policies in Nigerian Financial Institutions.' Asian Economic and Financial Review, 31: 62-74.

14. Sanni, M. R., Amusa, N. A., \& Agbeyangi, B. A. (2012). 'Potency of Monetary and Fiscal Policy Instruments on Economic Activities of Nigeria 1960-2011.' Journal of African Macroeconomic Review, 3(1): 161-176

15. Chuku, A. C. (2010). Monetary and fiscal policy interactions in Nigeria: An application of a statespace model with Markov switching. Journal of Applied Statistics, 1, 39-51.

16. Hilderbrand, P. (2013). Europe needs to focus more on reforms, not just austerity. The A-List

17. Adeoye, T. (2006). Fiscal policy and growth of the Nigerian economy: An empirical perspective (NISER Monograph Series, P 10). Ibadan, Nigeria: Nigerian Institute of Social and Economic Research.
18. Pesaran, M. H., Shin, Y., \& Smith, R. J. (2001). Bounds testing approaches to the analysis of level relationships. Journal of Applied Econometrics, 16: 289-326.

19. Pesaran, M., \& Pesaran, B. (1997). Microfit 4.0 (windows version). New York: Oxford University Press Inc.

20. Karmel P. H., \& Polasek M. (1980). Applied statistics for economists

21. Nworji, I. D., Okwu, A. T., Obiwuru, T. C, and Nworji, L. O. (2012). Effects of public expenditure on economic growth in Nigeria: A Disagragatted Time Series Analysis. International Journal of Management Sciences and Business Research, 1(7), 1-15

22. Medee, P. N., \& Nenbee S. G. (2011). 'Econometric Analysis of the Impact of Fiscal Policy Variables on Nigeria's Economic Growth 1970-2009.' International Journal of Economic Development Research and Investment, 2(1): 171183

23. Wu, S., Tang, J., \& Lin, E. (2010). The impact of government expenditure on economic growth: How sensitive to the Level of development. Journal of Policy Modeling, 32: 804-817

24. Philip, A. (2009). 'Fiscal Policy within the New Consensus Macroeconomics Framework.' Cambridge Centre for Economic and Public Policy (CCEPP) WP06-09. 